\title{
FINE NEEDLE ASPIRATION EXAMINATION PROFILE OF SOFT TISSUE TUMOR IN THE ANATOMICAL PATHOLOGY DEPARTMENT OF DR. SOETOMO GENERAL ACADEMIC HOSPITAL SURABAYA DURING 1 JANUARY 2014 - 31 DECEMBER 2018
}

\author{
Heriyawati* \\ *Corresponding author: heryawati4@gmail.com \\ Department of Anatomical Pathology, Faculty of Medicine, Airlangga University, Dr. Soetomo General \\ Academic Hospital, Surabaya, Indonesia
}

\begin{abstract}
Fine needle aspiration cytology is a rapid diagnostic technique and has advantages over traditional incisional biopsy. Fine needle aspiration cytology of soft tissue lesions, if supported by clinical and diagnostic data, will provide accurate results. Fine needle aspiration cytology has the advantage of significantly reducing discomfort, has a very low risk of complications, and can be performed from multiple sides, thus providing a more representative material. The aim of this study was to provide clinicopathological profile of fine needle aspiration cytology of soft tissue tumor in Anatomical Pathology Department of Dr. Soetomo General Academic Hospital during 2014 - 2018. This study used a descriptive observasional research with retrospective approach. The samples are all patient with soft tissue tumor which had fine needle aspiration cytology examination and with/without confirmation of histopathological examination at the Anatomical Pathology Department of Dr. Soetomo General Academic Hospital during 1 January 2014 - 31 December 2018. The data was obtained for five years, there were 244 cases of fine needle aspiration of soft tissue tumors, the most gender was female consist of 128 cases $(52.46 \%)$. There were more benign cases $(155$ cases $(63.52 \%))$ than malignant cases, and there were discrepancies in the results with histopathology in 9 cases (9.18\%) and with immunohistochemical examination in 5 cases $(5.10 \%)$.
\end{abstract}

Keywords: fine needle aspiration cytology, soft tissue tumor 


\section{Introduction}

Fine needle aspiration cytology is a rapid diagnostic technique and has several advantages, including there is no risk of tumor cells spreading through the biopsy site, reduces discomfort, has a very low risk of complications, and can be performed from various sides, thus providing a more representative material (Jain et al, 2017 ; Nayak et al, 2019).

Fine needle aspiration is very useful for differentiating benign soft tissue tumors from malignant ones, except for certain categories of tumors. Fine needle aspiration cytology as a preliminary diagnostic provides several advantages because it can predict the diagnosis of benign or malignant neoplasms, so surgery can be avoided in patients with benign neoplasms with poor surgical risk. In malignancy or cancer recurrence, fine-needle cytological aspiration allows palliative therapy (Nayak et al, 2019).

Soft tissue tumors are mesenchymal proliferations that occur outside the bone, non-epithelial tissue, outside the viscera, covering the brain and the lymphoreticular system including adipose tissue, fibrous connective tissue, muscle and bone, blood vessels and the peripheral nervous system. Soft tissue is almost entirely derived from the mesoderm except for the peripheral nerves. Soft tissue tumors comprise a large and heterogeneous group of tumors (Nayak et al, 2019).

This retrospective study describes the clinicopathological profile of fine needle aspiration in the case of soft tissue tumors examined at the Anatomical Pathology Department of Dr. Soetomo General Academic Hospital during 1 January 2014 - 31 December 2018.

\section{Material and Methods}

\section{Study Design}

The research design used was descriptive observational with a retrospective approach, because observations were made on events that had occurred previously using secondary data.

\section{Statistical Analysis}

This study used descriptive analysis of pathological characteristics of fine needle aspiration cases of soft tissue tumors patients which included age, gender, distribution of cases by location, cytomorphology diagnosis and discrepancy of the fine needle aspiration diagnosis with histopathology and immunohistochemistry examination. This study used data from fine needle aspiration cytology examination of soft tissue tumor specimens at the Anatomical Pathology Department of Dr. Soetomo General Academic Hospital during 1 January 2014 - 31 December 2018.

\section{Result}

In this study, during 1 January 2014 - 31 December 2018, there were 244 cases of fine needle aspiration examination of soft tissue tumors at the Anatomical Pathology Department of Dr. Soetomo General Academic Hospital. The most cases were in 2018 with 77 cases followed by 2016 with 70 cases.

Table 1. profile of fine needle aspiration in the case of soft tissue tumors examined at the Anatomical Pathology Department of Dr. Soetomo General Academic Hospital during 1 January 2014 - 31 December 2018.

\begin{tabular}{|c|c|c|}
\hline & Total & Percent (\%) \\
\hline \multicolumn{3}{|l|}{ Gender } \\
\hline Male & 116 & 47,34 \\
\hline Female & 128 & 52,46 \\
\hline \multicolumn{3}{|l|}{ Age Group } \\
\hline$<10$ y.o & 32 & 13,11 \\
\hline $10-20$ y.o & 19 & 7,87 \\
\hline $21-30$ y.o & 21 & 8,6 \\
\hline $31-40$ y.o & 40 & 16,39 \\
\hline $41-50$ y.o & 47 & 19,26 \\
\hline $51-60$ y.o & 48 & 19,67 \\
\hline $61-70$ y.o & 29 & 11,84 \\
\hline$>70$ у.о & 8 & 3,26 \\
\hline \multicolumn{3}{|l|}{ Location } \\
\hline Upper extremities & 42 & 17,21 \\
\hline
\end{tabular}




\begin{tabular}{|c|c|c|}
\hline Lower extremities & 63 & 25,82 \\
\hline Head & 44 & 18 \\
\hline Trunk & 71 & 28,98 \\
\hline Neck & 25 & 10,24 \\
\hline \multicolumn{3}{|c|}{ Cytomorphology Diagnosed } \\
\hline Benign & 155 & 63,52 \\
\hline Malignant & 87 & 35,65 \\
\hline Unclear & 2 & 0,82 \\
\hline \multicolumn{3}{|c|}{ Cytomorphological Pattern } \\
\hline Spindle cell neoplasma & 85 & 34,84 \\
\hline Miksoid neoplasma & 11 & 4,5 \\
\hline Fibrohistiocytic neoplasma & 17 & 6,97 \\
\hline Round cell neoplasma & 26 & 10,66 \\
\hline Pleomorphic neoplasma & 9 & 3,7 \\
\hline Adipocytic neoplasma & 96 & 39,34 \\
\hline \multicolumn{3}{|c|}{ Differential Diagnosis } \\
\hline With differential diagnosis & 41 & 16,8 \\
\hline Without differential diagnosis & 203 & 83,2 \\
\hline
\end{tabular}

Table 2. Distribution of discrepancies in cytomorphological results with histopathological and immunohistochemical examinations

\begin{tabular}{|l|l|l|l|l|}
\hline \multirow{2}{*}{ Examination } & \multicolumn{2}{|c|}{ Total } & \multirow{2}{*}{ Percent (\%) } & \multicolumn{2}{c|}{ Discrepancy } \\
\cline { 3 - 5 } & & & & \multicolumn{2}{|c|}{ Total } & Percent (\%) \\
\cline { 3 - 6 } & & & 88,52 & 8,16 \\
\hline Histopatology & 98 & 9,43 & 5 & 5,10 \\
\hline Imunohistochemistry & 23 & \multicolumn{3}{|c|}{} \\
\hline
\end{tabular}

Table 3. Distribution of fine needle aspiration results with histopathological examination based on cytomorphological patterns.

\begin{tabular}{|c|c|c|c|c|c|}
\hline \multirow[t]{2}{*}{ Cytomorphology Pattern } & \multicolumn{2}{|c|}{ Histopatology } & \multirow{2}{*}{$\begin{array}{l}\text { Acco } \\
\text { rdan } \\
\text { ce }\end{array}$} & \multirow[t]{2}{*}{ Discrepancy } & \multirow[t]{2}{*}{ Cytodiagnosed } \\
\hline & $\begin{array}{l}\text { Malig } \\
\text { nant }\end{array}$ & Benign & & & \\
\hline Spindle cell neoplasm & 12 & 28 & 36 & $\begin{array}{l}2 \\
\text { Synovial } \\
\text { sarcoma, } \\
\text { sarcoma }\end{array}$ & $\begin{array}{l}\text { Fibrohistiocytic } \\
\text { lesion, benign } \\
\text { mesenchymal } \\
\text { lesion }\end{array}$ \\
\hline Myxoid neoplasm & 6 & 0 & 0 & 0 & \\
\hline Fibrohistiocytic neoplasm & 1 & 4 & 5 & 0 & \\
\hline Round cell neoplasm & 10 & 0 & 10 & 0 & \\
\hline Pleomorphic neoplasm & 8 & 0 & 8 & 0 & \\
\hline Adipocytic neoplasm & 1 & 23 & 23 & $\begin{array}{l}1 \\
\text { well } \\
\text { differentiated } \\
\text { liposarcoma }\end{array}$ & lipoma \\
\hline \multicolumn{6}{|l|}{ Non neoplasm } \\
\hline a. Inflamation & & & & 4 & $\begin{array}{l}\text { benign } \\
\text { mesenchymal } \\
\text { lesion, benign } \\
\text { fibrous } \\
\text { histicytoma, } \\
\text { neurofibromatosis, } \\
\text { lipoma }\end{array}$ \\
\hline
\end{tabular}




\begin{tabular}{|l|l|l|l|l|l} 
b. keloid & & & & 1 & fibroma
\end{tabular}

There were cases of the discrepancy between the case of fine needle aspiration of soft tissue tumors with histopathology and immunohistochemistry.

\section{Spindle cell neoplasm}

Case 1

48-year-old man with a mass in the parietal region. On fine needle aspiration, it was concluded that the mesenchymal spindle tumor had a neurogenic origin. Then a histopathological examination of the surgical material for the right temporoparietal tumor was performed. It was concluded that it was a malignant spindle mesenchymal tumor. The differential diagnosis was: 1. Synovial sarcoma, monophasic; 2. Malignant peripheral nerve sheath tumor; 3. Fibrosarcoma. Suggestions for immunohitochemical examination with CK, EMA, S100, SMA antibodies. On immunohistochemical examination, the staining with SMA was focal positive on the cytoplasm of tumor cells, while staining with CK, EMA, and S100 was negative on tumor cells, which was concluded according to fibrosarcoma.
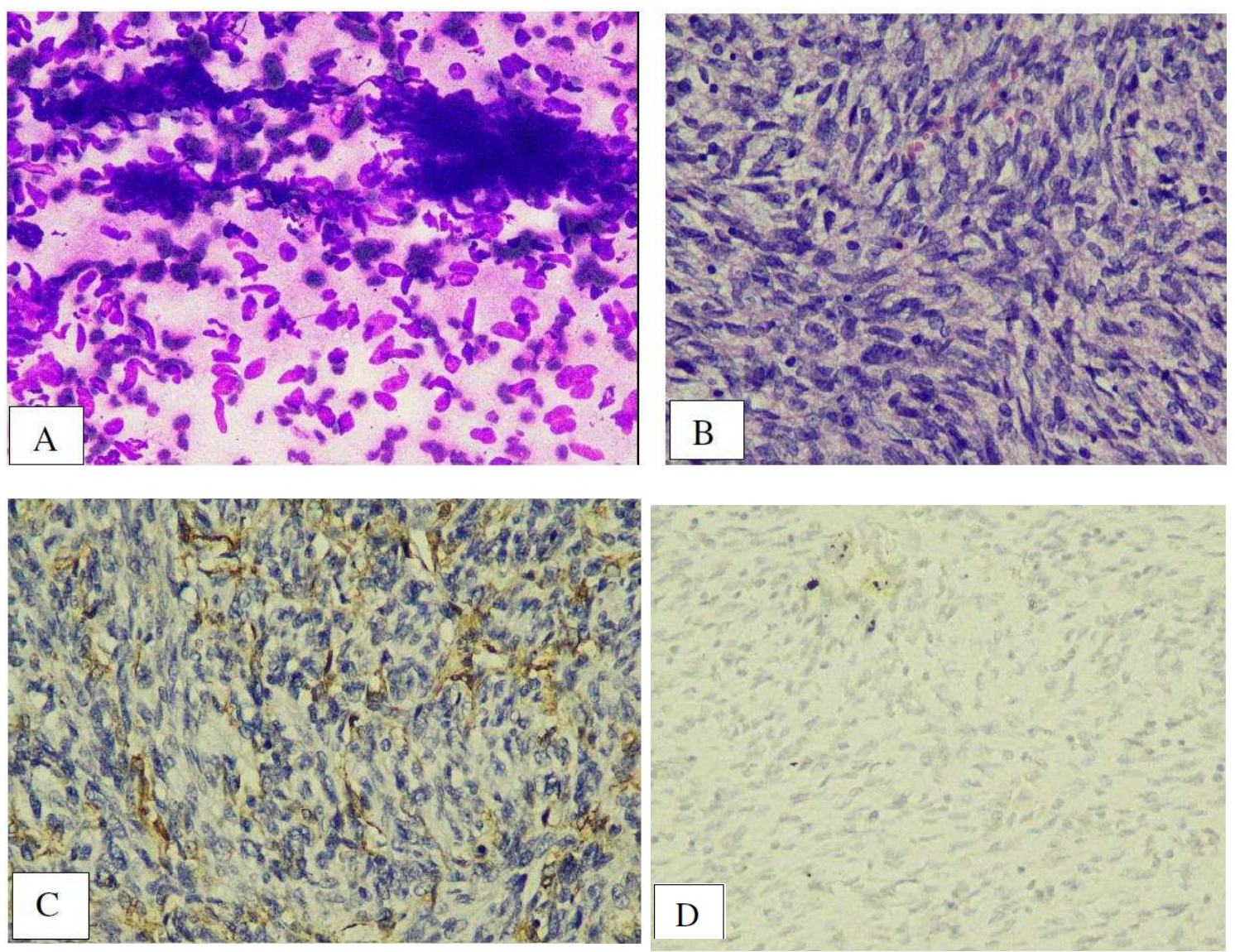


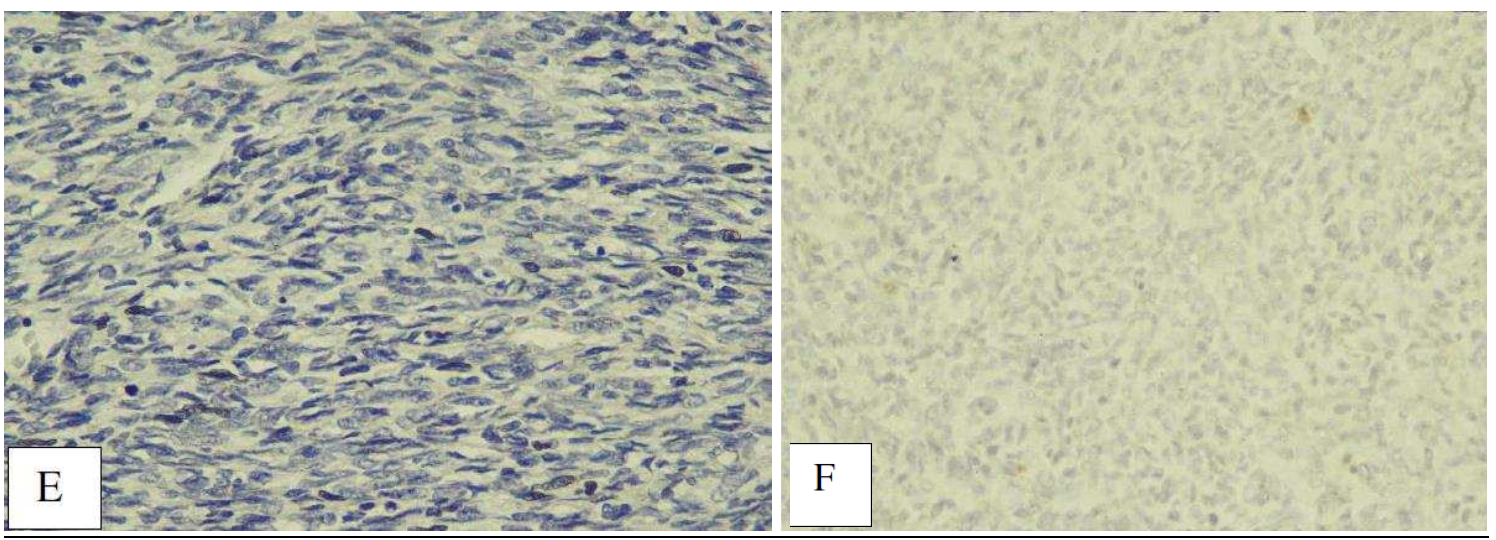

Picture A. Shows smears with spindle- and wavy-shaped cells, fine chromatin, light pleomorphism, and eosinophilic matrix (Diff Quick). B. Malignant tumor tissue with spindle-plump cell proliferation, pleomorphic, hyperchromatic, arranged in intersecting fascicles (HE). C. On staining with SMA, a focal positive was found in the cytoplasm of tumor cells. D.E.F On staining with CK, EMA, S100, respectively, the tumor cells were negative. (400x)

\section{Case 2}

48-year-old man with a frontoparietal mass. On examination, fine needle aspiration was concluded as a benign mesenchymal lesion. Then histopathological examination of the wide excision material was carried out, it was concluded that it was a malignant spindle mesenchymal tumor, the differential diagnosis was: 1. Malignant peripheral nerve sheath tumor; 2. Fibrosarcoma; 3. Synovial sarcoma. Suggestions for immunohitochemical examination with antibodies S100, Vimentin, PanCK. On immunohitochemical examination, the preparations were positive with Vimentin staining, negative with PanCK and S100 staining. Then it was concluded sarcoma (Vimentin positive), with a negative PanCK note ruling out synovial sarcoma. Cannot exclude malignant peripheral nerve sheath tumor even though S100 is negative. Additional immunohistochemistry with SMA and Desmin antibodies (to exclude leiomyosarcoma) and CD34 is required to exclude hemangipericytoma.
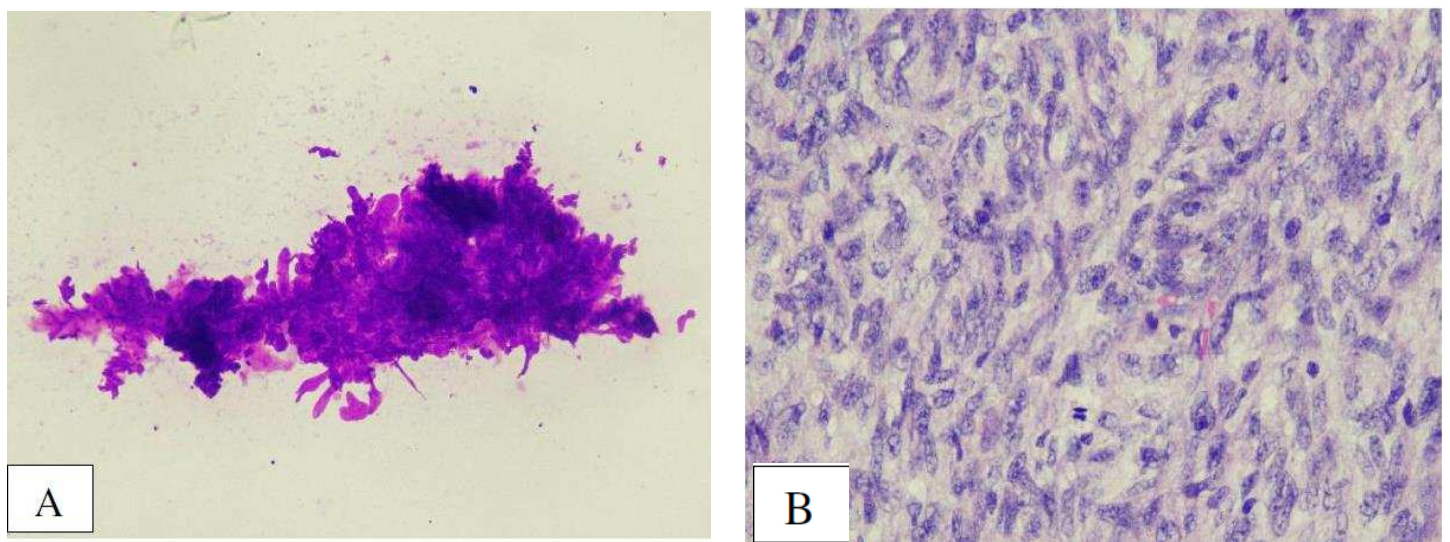

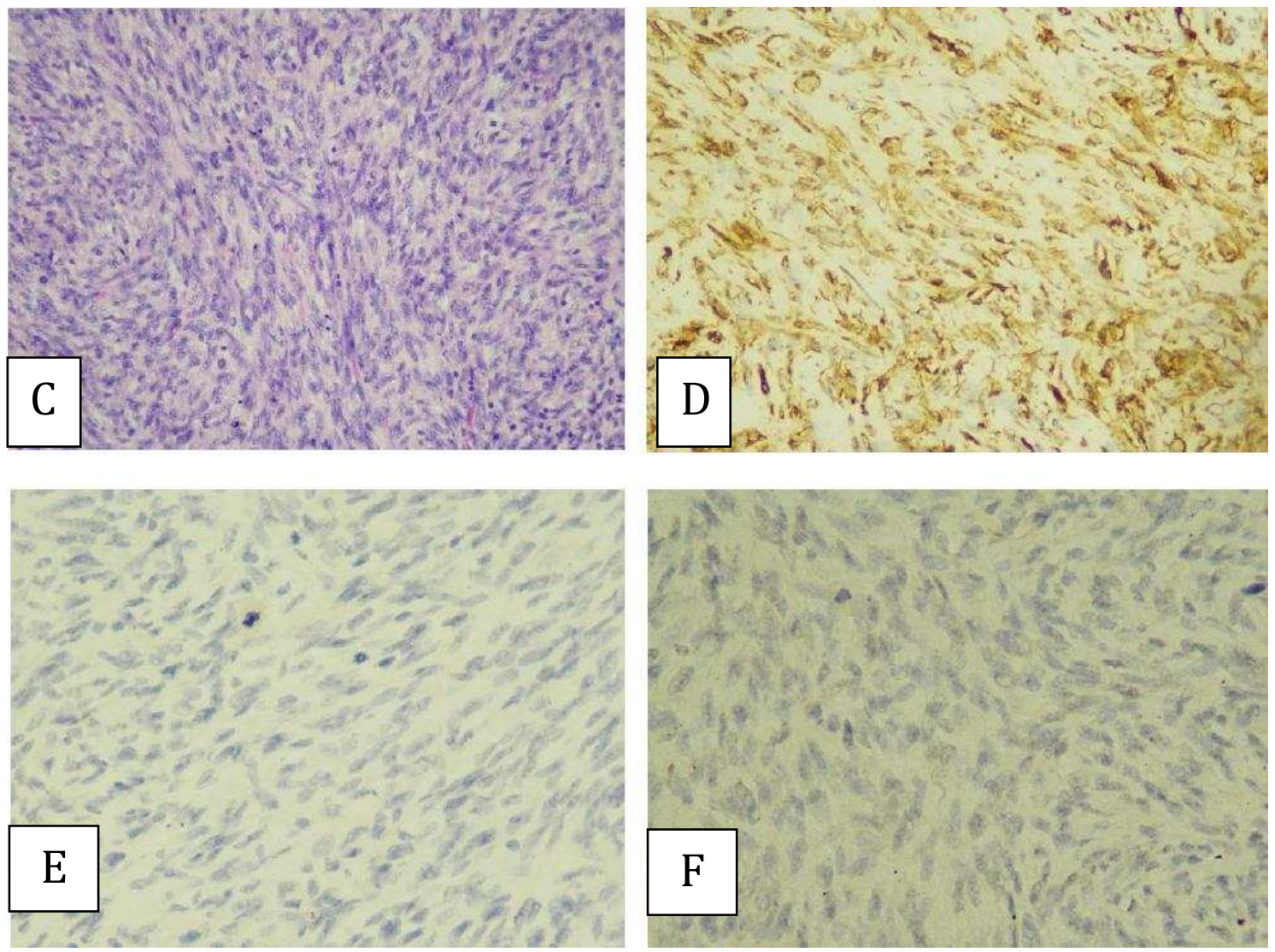

Picture A. Shows smears with distribution and clusters of oval to spindle nuclei, fine chromatin, thin cytoplasm. (Diff Quick, 400x) B,C. Malignant tumor tissue with anaplastic spindle cell proliferation, oval to spindle nuclei, coarse chromatin, arranged in long, crossed fascicles. (HE, 200x;400x) D. On staining with positive vimentin on tumor cells. E,F. On staining with panCK, and S100, respectively, the tumor cells were negative. (400x)

Case 3

48 years old male with left axillary region mass, on fine needle aspiration examination concluded mesenchymal spindle tumor, residual neurofibroma impression. On histopathological examination of the biopsy preparations concluded residual neurofibroma. Then on immunohistochemical examination with S100 antibodies, the tumor cells were negative. so that it is concluded that it is not in accordance with neurofibroma, in accordance with fibromatosis. 

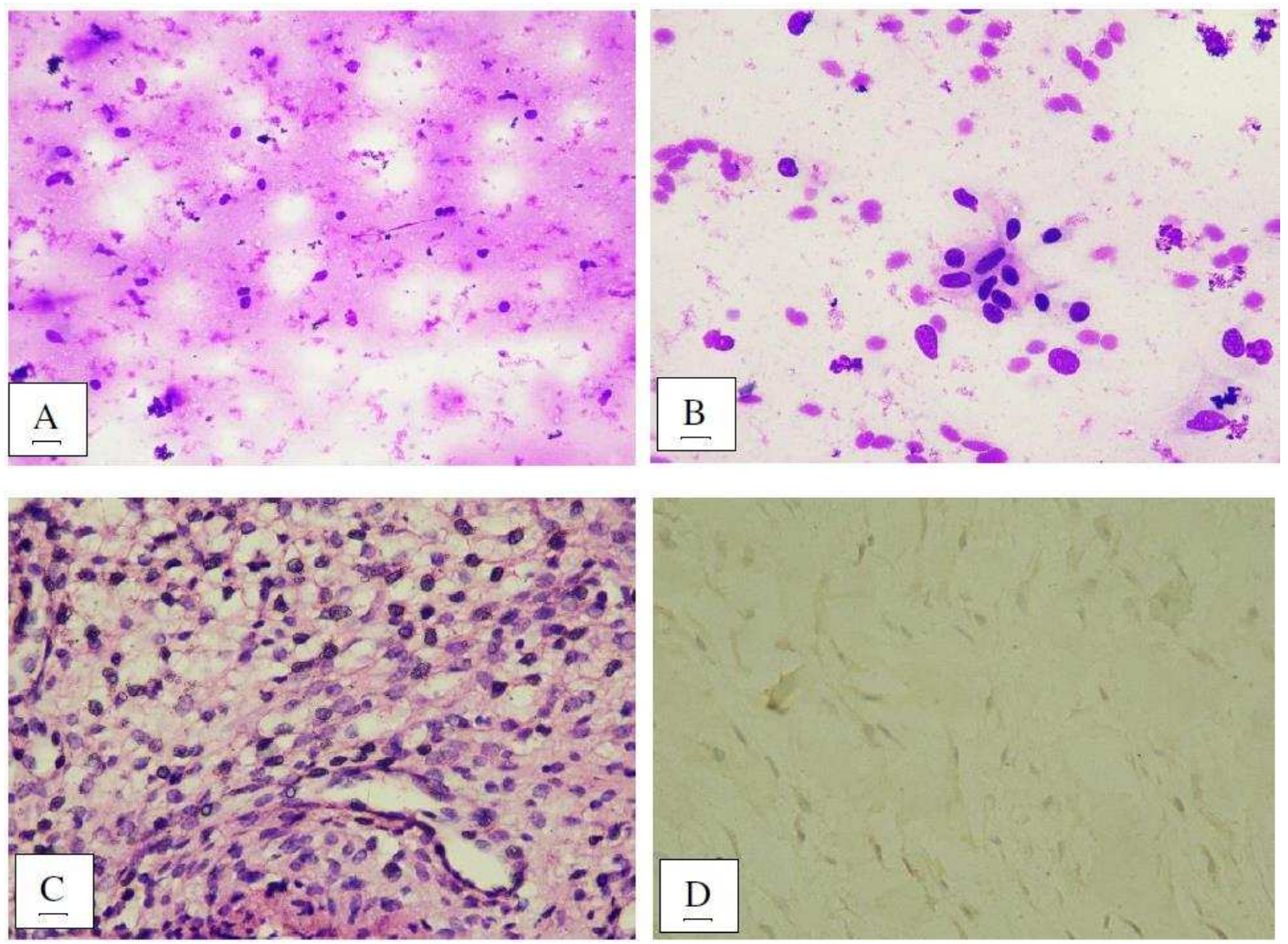

Picture A. (Diff Quick, 200x). B. Shows sufficient smears of cells with round oval to spindle cell distribution, fine chromatin, sufficient cytoplasm (Diff Quick, 400x). C. Tumor tissue arranged in fascicles with proliferation of oval to spindle nuclear cells, fine chromatin (HE, 400x). D. Staining with S100 was negative for tumor cells (400x).

\section{Case 4}

A 70-year-old man with nodules in the temporoparietal region, concluded the impression of a malignant spindle mesenchymal tumor that is difficult to determine cytologically. On histopathological examination of the operative tissue, the differential diagnosis was concluded: 1. Malignant fibrous histiocytoma; 2. Malignant peripheral nerve sheath tumor; 3. Rhabdomyosarcoma, with the suggestion of immunohistochemical examination with vimentin antibody, S100, Desmin, SMA. On immunohistochemical examination, the tumor cells were positive with Vimentin and CK staining, while S100, Desmin, and SMA were negative for tumor cells. The conclusion from immunohistochemistry is that sarcoma corresponds to poorly differentiated. 

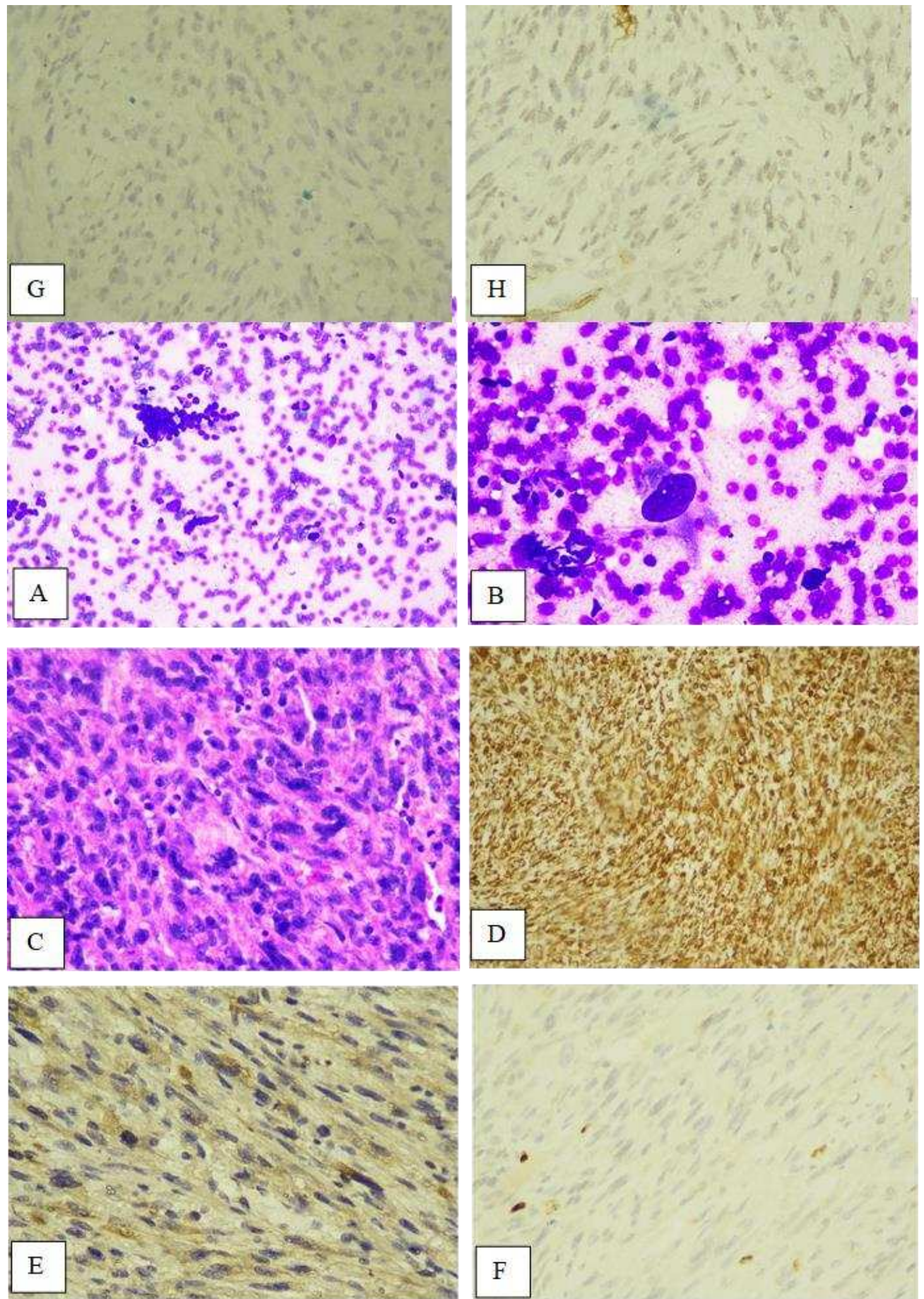

Picture A. (Diff Quick, 200x), B. (400x) Indicates enough cell smears containing scattered and clusters of round to spindle nucleated cells, coarse chromatin, sufficient cytoplasm. C. The tumor tissue was composed of solid, some fascicles and trabecular with proliferation of oval to spindle round nuclear cells, heavy pleomorphic, hyperchromatic, some nuclei visible to the edge, thin cytoplasm (HE, 400x). D, E. On staining with vimentin and positive CK on tumor cells, respectively (400x). F,G,H. S100, Desmin, and SMA were negative on tumor cells, respectively (400x). 


\section{Round cell neoplasm}

Case 1

51-year-old woman with a soft tissue mass in the left palmar region. On fine needle aspiration examination, it was concluded that it was a malignant round cell tumor according to primitive neuro ectodermal tumor (PNET), with a confirmed histopathological examination followed by immunohistochemical examination. On histopathological examination of the biopsy material, it was concluded that it was a malignant round cell tumor, the differential diagnosis was: 1. Primitive neuro ectodermal tumor, 2. Neuroendocrine carcinoma in the skin (Merkel cell carcinoma), with the recommendation of immunohistochemical examination with antibodies CK20, vimentin, CD99, S100, Chromogranin, synaphtophysin. On immunohistochemical examination, the tumor cells were positive with panCk staining and weak-focal positive with synaphtophisin staining. On staining with CK20, vimentin, CD99, S100, Chromogranin was negative on tumor cells. The conclusion does not support either PNET or Merkel cell carcinoma, more in line with poorly differentiated squamous cell carcinoma.
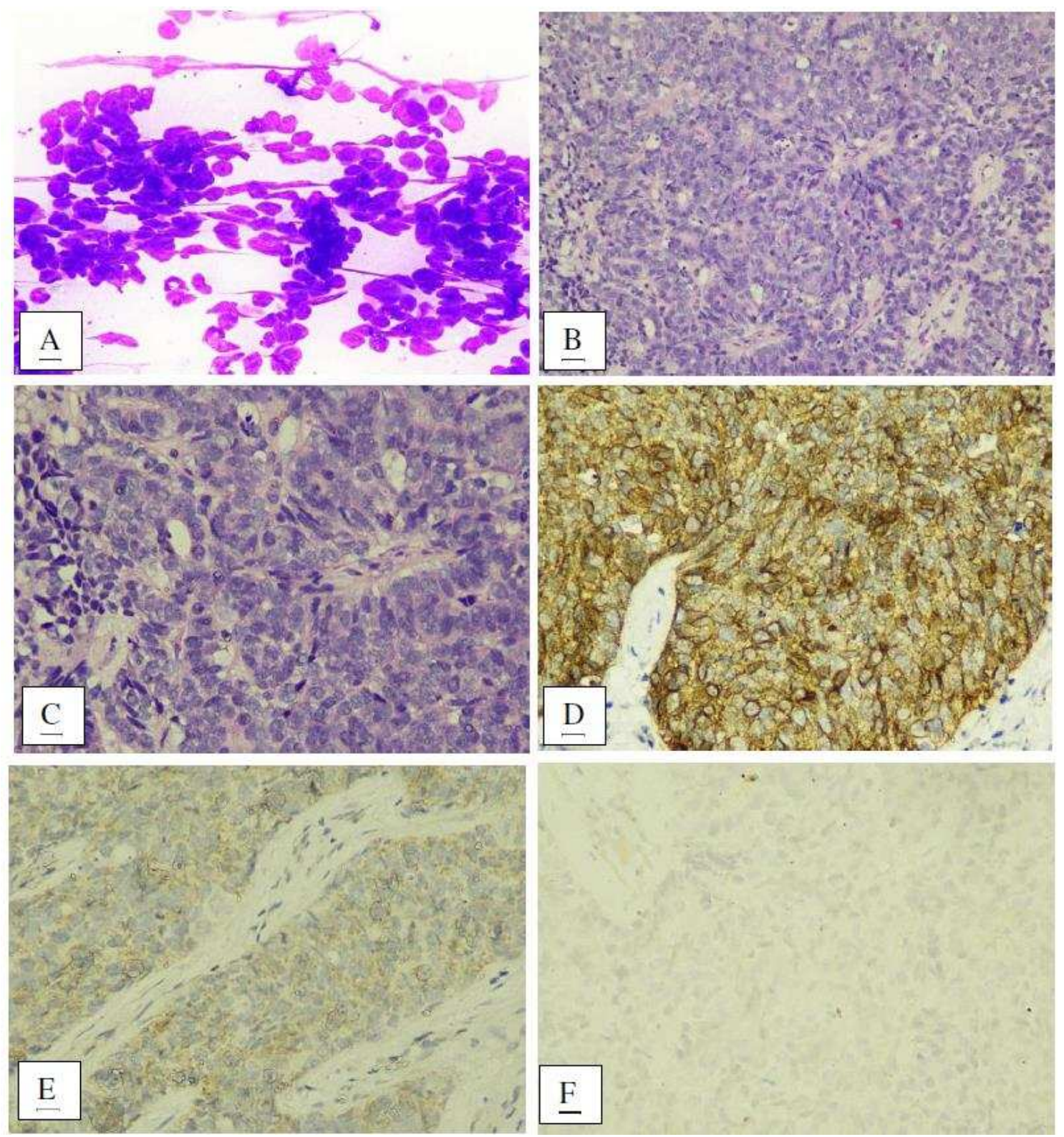

Picture A. Shows hypercellular smears with clusters and distribution of round-oval, pleomorphic, salt and pepper chromatin cells, some arranged in pseudorosettes (Diff Quick, 400x). B, ( HE, 200x) C. Tumor tissue arranged in nests, with proliferation of round, oval, pleomorphic, hyperchromatic nuclear cells, 
visible nucleus, visible rosette formation (HE, 400x). D. Staining with panCK is positive for tumor cells. E. Staining with synaphtophysin was found to be focally positive and weak in tumor cells. F, G, H, I, J. Each tumor cell was negative by staining CK20, vimentin, CD99, S100, and Chromogranin (400x).
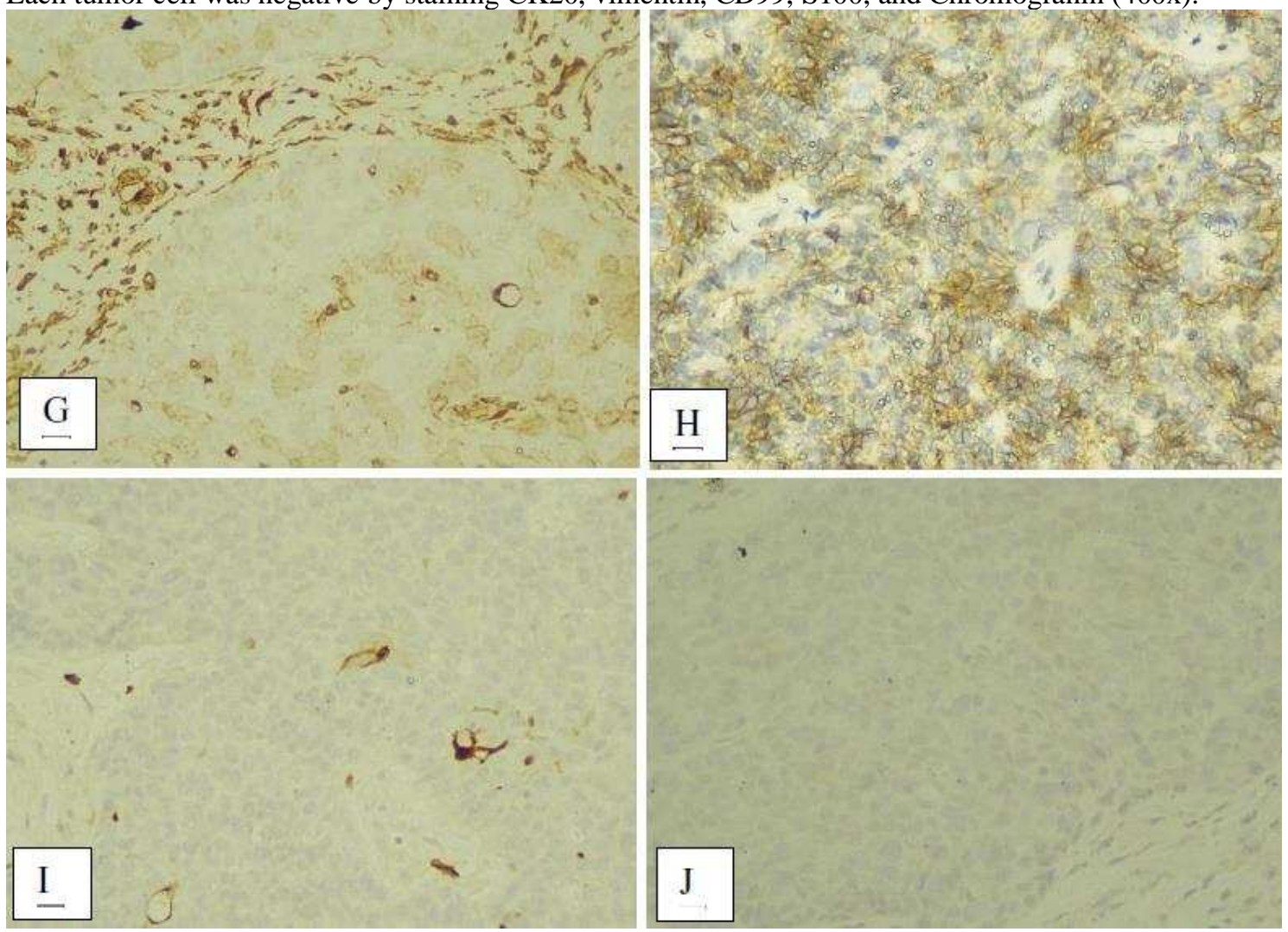

\section{Discussion}

Soft tissue tumors are very large areas. The incidence of soft tissue tumors is rare and the differences in tumor types are wide ranging, diagnosis and classification of soft tissue tumors being the most difficult field of pathology and the absence of recognizable tissue architectural patterns in cytology preparations makes the diagnosis by fine needle aspiration cytology become more difficult (Cibas and Ducatman, 2014).

Fine needle aspiration is very useful in differentiating benign soft tissue tumors from malignant ones, except for certain categories of tumors. Fine needle aspiration cytology as a preliminary diagnostic provides several advantages because it can predict the diagnosis of benign or malignant neoplasms. Benign tumors are found more often than malignant in a ratio of 10 to 100:1 (Soni et al., 2014 and Iyer, 2008).

In this study, the mean age was 30.6 years, the youngest age at diagnosis was 9 months while the oldest age was 83 years. Distribution of patients by age group was divided into 8 groups with a span of 10 years. The highest number of patients was found in the age group of 51-60 years, a total of 48 patients (19.67\%). This is almost the same as the literature. According to Goldblum et al, based on Surveillance, Epidemiology and End Result data, the incidence of soft tissue tumors changed with age, for children younger than 10 years, the annual incidence was $0.9 / 100,000$ children, but increased to $18.2 / 100,000$ over the age of 70, with a sharp increase between the ages of 30 and 70 . While soft tissue sarcoma distribution can occur at all ages, and is more common in old age (Goldblum et al., 2013). In addition, there is a correlation between the type of soft tissue tumor and age, because certain tumors occur at a certain age, so if there is clinical data on age, it will be easier to determine the type of soft tissue tumor (Norahmawati, 2020).

The majority of patients with soft tissue tumors, both malignant and benign, who were examined at the Anatomical Pathology Laboratory of RSUD Dr. Soetomo Surabaya during the period 1 January $2014-$ 
31 December 2018 were male, with a total of 116 patients (47.34\%). For the female gender, there were 128 patients $(52.66 \%)$. These results are inconsistent with the reference that soft tissue malignancies occur more frequently in men, but the incidence related to sex and age varies depending on the histological type (Goldblum et al., 2013). A study conducted by Rekhi et al, found that the number of patients with soft tissue tumors was slightly higher in men than women with a ratio of 1.8:1 (Rekhi et al., 2007).

Based on the location of the case, fine needle aspiration examination of soft tissue tumors, including those involving the upper extremities, lower extremities, head, trunk, and neck. The most locations on the trunk were 71 cases $(28.98 \%)$, covering the back, chest, shoulders, buttocks, and inguinal area, then the lower extremities as many as 63 cases $(25.82 \%)$. The results of the study are not much different from the reference which states that soft tissue malignancies can occur in any part of the body, but most commonly occur in the lower extremities, chest wall, mediastinum, and retroperitoneum (Goldblum et al., 2013). In addition, the location of the tumor can also help diagnose because there are several types of soft tissue tumors that are typically located in certain body parts such as in the extremities or intra-abdominal (Norahmawati, 2020).

The cytomorphological diagnosis of fine needle aspiration of soft tissue tumors examined in the Anatomical Pathology laboratory of RSUD Dr. Soetomo Surabaya during the period 1 January $2014-31$ December 2018 found 154 benign cases and 87 malignant cases, as well as 2 cases without malignancy classification. A study by Iyer stated that the incidence of benign soft tissue tumors was approximately 10 times that of malignant ones (Iyer, 2008). While lipomas occur mainly in adults over 30 years of age, they are very common and account for half of all soft tissue tumors (Cibas and Ducatman, 2014). Research conducted by Rekhi et al, stated that the most common cases found were spindle cell neoplasms (Rekhi et al., 2007). The number of diagnoses of fine needle aspiration of soft tissue tumors followed by histopathological examination were $94(38.52 \%)$ cases, with a discrepancy between the results of cytomorphology and histopathology as many as 8 cases $(8,16 \%)$. Cases with histopathological examination followed by immunohistochemical examination were 23 cases (29.1\%), with a discrepancy between cytomorphological results and immunohistochemical results in 5 cases $(5.10 \%)$. The results of this study are in line with the literature which states that a systematic approach to differential diagnosis can increase the cytopathologist's efforts to experience the obtained. Investigations other than immunohistochemistry are often very necessary for definitive classification (Cibas and Ducatman, 2014). In addition, the heterogeneity of the diagnosis of complex soft tissue tumors can be a limiting factor for appropriate categorization (Rekhi et al., 2007). Differential diagnosis with similar cytological features is also needed if there is difficulty in determining the specific subtype or subclassification of the tumor with certainty (Norahmawati, 2020).

There were 39 cases of fine needle aspiration which were confirmed by histopathological examination. On histopathological examination, there were 2 cases of discrepancy in spindle cell neoplasms, while there were 5 cases that were not neoplasms, in the form of inflammation, keloids. These results are consistent with the literature which states that more than $87-100 \%$ of cases are correctly diagnosed as benign or malignant, with a sensitivity and specificity for malignancy of approximately $95 \%$. There are three factors that cause misdiagnosis, namely sampling error, limited specimens, and misinterpretation. The false positive rate for fine needle aspiration of soft tissue tumors is relatively low (0 to 5\%). The false negative rate varies slightly (2 to 15\%) (Cibas and Ducatman, 2014). The discrepancy of the results with histopathology can be caused by cystic tumors, large tumors with extensive necrosis, tumors with extensive fibrosis/desmoplasia or collagenization and vascular or hypervascular tumors, resulting in hypocellular smears (Norahmawati, 2020).

\section{Conclusion}

Most patients with soft tissue tumors were women, the most cytomorphological diagnosis was benign cases of $155(63.52 \%)$, the cytomorphological pattern of fine needle aspiration of soft tissue tumors was adipocytic cell neoplasm, which was 96 cases (39.34\%), There were 8 out of 98 cases that did not match the histopathological diagnosis and biopsy aspiration, there were 5 out of 23 cases that did not match between immunohistochemical examination and biopsy aspiration. 


\section{References}

Akerman M., Domanski, H.A. (2003). The cytology of soft tissue tumours. Monogr Clin Cytol.;16:1-112, IX-X.

Antonescu, C.R., Zhang, L., Nielsen, G.P., Rosenberg, A.E., Dal Cin, P., Fletcher, C.D. (2011). Consistent $\mathrm{t}(1 ; 10)$ with rearrangements of TGFBR3 and MGEA5 in both myxoinflammatory fibroblastic sarcoma and hemosiderotic fibrolipomatous tumor. Genes Chromosomes Cancer.;50(10):757-764.

Cibas, E.S., Ducatman, B.S. (2014). Cytology: diagnostic principles and clinical correlates. Hal.471-514. Elsevier: Philadelphia.

Fletcher, C.D.M. (2007). Diagnostic Histopathology of Tumors. 3rd ed. London: Churchill Livingstone.

Fletcher, C.D.M., Bridge, J., Hogendoorn, P., Mertens, F. (2013). World Health Organization Classification of Tumours. Pathology and Genetics of Tumours of Soft Tissue and Bone. 4th ed. Geneva, Switzerland: IARC Press.

Hollmann, T.J., Hornick, J.L. (2011). INI1-deficient tumors: diagnostic features and molecular genetics. Am J Surg Pathol:;35(10):e47-e63.

Iyer, V. K. (2008) "Cytology of soft tissue tumors: Benign soft tissue tumors including reactive, nonneoplastic lesions," Journal of Cytology, 25(3), hal. 81-86. doi: 10.4103/0970-9371.44034.

Jain, V. dan Agarwal, T. (2017) "Role of FNAC in soft tissue tumors and its histopathological correlation," International Surgery Journal, 4(8), hal. 2632. doi: 10.18203/23492902.isj20173402.

Kapila, K., Ghosal, N., Gill, S.S., Verma, K. (2003). Cytomorphology of lipomatous tumors of soft tissue. Acta Cytol.;47(4): 555-562.

Nayak, S., Dutta, G., Kaustav, M., Agarwal, K. C. (2019) "Original Research Paper Pathology. Fnac of soft tissue tumor with histopathological correlation in western odisha- a 7years prospective and retrospective study . (2), hal. 20-22.

Norahmawati. (2020). Biopsi aspirasi jarum halus. Tumor jaringan lunak. Dep. Patologi Anatomik FKUB-RSSA: Malang.

Rege, T.A., Madan, R., Qian, X. (2012). Long fascicular tissue fragments in desmoid fibromatosis by fine needle aspiration: a new cytologic feature. Diagn Cytopathol.;40(1):45-47.

Soni, P. B. et al. (2014) "A prospective study of soft tissue tumors istocytopathology correlation," Pathology Research International, 2014. doi: 10.1155/2014/678628. 